\title{
Formation of Religious Culture Based on Information Technology in Pesantren
}

\author{
S Mutholingah ${ }^{1}$ \\ STAI Ma’had Aly Al-Hikam, Malang, Indonesia. \\ \{siti.mutholingah89@gmail.com $\left.{ }^{1}\right\}$
}

\begin{abstract}
Pesantren is an Islamic educational institution that has distinctive characteristics, which is a deeply religious culture. However, along with the industrial revolution 4.0 that brought influence in various aspects of this life, pesantren should face problems, one of which is the erosion of its religious culture. Therefore, pesantren needs to address widely the unavoidable development of information technology, giving new color to religious culture in pesantren that is strongly nuanced but up-to-date Islamic teachings. This paper seeks to examine the formation of religious culture based on information technology that can provide an alternative in facing the problem. A multidisciplinary perspective, namely social, economic and psychological, are used in the analysis. The research method was a literature review with a content data analysis. The results of the study include: 1) Religious values that can be developed through the religious culture based on information technology in pesantren include divinity, humanity, and nationality; 2) The implementation of the religious culture based on information technology in a multidisciplinary perspective showed that a) a social perspective can be done by developing students' skills through communication and information media; b) an economic perspective by developing entrepreneurial skills based on information technology; c) a psychological perspective by tazkiyah al-nafs.
\end{abstract}

Keywords: Religious Culture,Pesantren, Information Technology

\section{Introduction}

Historically, pesantren is an Islamic educational institution that for centuries has been growing and developing in Indonesia with the characteristics of a very deep religious culture. Religious culture that has been developing in pesantren is the result of the acculturation of Islamic values with local cultures. Nurcholis Madjid argues that pesantren in Indonesia are indigenous, meaning that they are not only identical to Islamic values, but it also contains Indonesian authenticity [1]. Thus, from a historical perspective, pesantren has become a center of growth and spread of Islamic sciences in order to strengthen the teachings of Islam (li al-tafaqquh fi al-din) [2]. In other terms, pesantren is of religious culture development.

On the other hand, the current era of globalization and digitalization which is known as the industrial revolution 4.0 has an impact on various aspects of life, one of which is the impact on pesantren life. This modern era is the most uncomfortable era for the existence of traditions developed by pesantren [3]. How come? The pesantren, which is actually an educational institution that is very thick with religious and indigenous nuances, is in line with 
the development of the times and the industrial revolution 4.0 which brings influence in various aspects of life. But, if the pesantren does not keep up with technological development 4.0 , the pesantren will be outdated.

Based on that pesantren's dilemma problem, it is very urgent to establish an information technology-based religious culture at pesantren. So, in this case, the pesantren can wisely facilitate its students to utilize the development of information technology as a selfactualization media but still in the context of the religious culture that exists in the pesantren. So, the characteristics of religious viscosity in pesantren will be maintained, but students will be able to keep up with the times, especially in the industrial revolution 4.0 and digitalization era.

\section{Method}

The research method was used in this study was a literature review or library research with data analysis used content analysis. According to M. Nazir, a literature study is a data collection technique by conducting study studies of books, literature, notes, and reports related to the problems that have been raised [4]. The analysis of the data using content analysis. As states by Elo and Kyngas, content analysis is a research method for the subjective interpretation of the content of text data through the systematic classification process of coding and identifying themes or patterns [5].

Thus, in this study, the data obtained from sources in the form of textbooks, journals and scientific articles the author examines in-depth and classifies which ones are related to the formation of information technology-based religious culture in pesantren. Furthermore, for the purpose of discussion from a multidisciplinary perspective, the researcher examines it from three perspectives: social, economic, and psychological.

\section{Result and Discussion}

\section{Religious Values Developed through the Religious Culture Based on Information Technology in Pesantren}

\section{Religious Values}

Value is a belief that is the basis for a person or group to choose their actions or assess something that is meaningful or not for their lives [6]. Robbins added that values affect attitudes and behavior [7]. So, value is something abstract that is believed by someone so that it is used as a basis for determining whether an action is carried out according to that value.

Religious values are one of the various value classifications. It comes from religion and can penetrate into the soul's intimacy. Religious values need to be instilled in educational institutions to form a stable and robust religious culture in these educational institutions [6]. Religious values are the basis of the formation of religious culture because, without the inculcation of religious values, a religious culture will not be formed.

\section{Religious Culture at Pesantren}

Religious culture, as expressed by Fathurrohman, is an effort to realize the values of religious teachings as a tradition in behavior and organizational culture that is followed by all citizens in educational institutions [6]. Chotimah said that religious culture is an effort to 
realize the values of religious teachings as a tradition in the behavior and organizational culture that is followed by all the people in it, where the tradition has been embedded in the hearts of every individual who has carried out religious teachings [8]. Religious culture functions to guide and direct human beings to be aware of their existence as limited human beings, as well as to foster an attitude of faith and piety to God who is all-powerful [9]. Thus, religious culture is a way of thinking and how to act in a group or organization based on religious values.

Muzayin Arifin defines pesantren as a religious educational institution, with a dormitory system, that grows and is recognized by the surrounding community. The main purpose of pesantren education, as revealed by Sahal Mahfud, is to form or prepare human beings who are pious and able to become khalifah on earth to achieve the world and hereafter happiness [10]. So what is meant by religious culture in pesantren is a set of religious values that underlie the behaviors, traditions, daily habits, and symbols practiced by pesantren residents in order to form and prepare students to be more individually and socially pious and noble human beings.

\section{Utilization of Information Technology in the Formation of Religious Culture in Pesantren}

Henry, quoted by Hanun, mentioned that information technology is a technology used to process data, including processing, obtaining, compiling, storing, manipulating data as a way to produce quality information, namely information that is relevant, accurate, and timely used to personal, business, and governance needs which are strategic aspects for decision making [11]. Meanwhile, Rahmat argued that information technology includes matters relating to the process, manipulation and management of information [12]. Information technology-based education can be carried out correctly if the requirements related to the availability of technology, mastery of knowledge, and skills to develop policy contents and community readiness are fulfilled.

Then in the context of the formation of religious culture in pesantren, information technology can be utilized through several activities, including:

a) Utilization of digital al-Qur'an in pesantren, namely the existence of digital al-Qur'an developed in pesantren will undoubtedly make it easier for students to get used to reading the Qur'an;

b) Utilization of software such as Islamic syllables to add to book literature in pesantren which is used as a reference;

c) The wise use of social media such as Facebook, Whatsapp and others to develop $d a^{\prime} w a h$ in pesantren;

d) Utilization of youtube media to upload religious activities in pesantren, such as socializing dhikr and prayers together through youtube.

\section{Religious Values Developed through the Religious Culture Based on Information Technology in Pesantren}

\section{Value of Divinity}

Divine values are born of a belief in the form of guidance from the supernatural or God [13]. Divine values have the most reliable basis of truth compared to other values. This is because this value comes from the highest truth from God [14]. Nisa argued that divine values have a higher vertical position than other living values [15]. Thus, these divine values are the 
most essential and fundamental values that must be taught and instilled in every generation of Muslims, including in this case, to students in pesantren.

The divine values that can be instilled in students through the formation of religious culture as expressed by Isna include(1) Faith;(2) Ubudiyah; and (3) Mu'amalah [13]. Faith has a high position in human life. The worldview controls human because faith is a world view, humans are controlled by their faith [15]. Since in mahuh ul-mahfudz, humans are not valuefree creatures. A primordial covenant binds humans with their creator, which is a statement of unity to Allah (Q. al-A'raf: 172). The existence of this primordial agreement makes every human being equipped with instincts or religious potential (hidāyāt diniyyah), namely the urge to serve something that he considers has higher authority [16]. Therefore, this value of faith becomes the most critical religious value to be instilled and internalized to students. This value of faith becomes the foundation in the development of other divine values.

Abu Hasan Ali defined ubudiyah being humble and submissive, meaning that every creature whether it is a genie or a human being is all subject to Allah's qadla' (ruling), following the will of Allah, all of them do not have the power to get out of the purpose created by Allah [17]. This is in line with the main purpose of human creation, which is to worship Allah SWT. (Q.S. Adz Dzariyat: 56). Ubudiyah is an impact of the belief in which servitude is directed to the most powerful in its essential meaning [18].

Mu'amalahis a part of the Islamic law that regulates the relationship between two or more parties or between the individuals [19]. In the matter of mu'amalah, Islamic law gives more general patterns, principles, and rules rather than giving the types and forms of mu'amalah in detail. That is, in mu'amalah, important issues are the substance of the meaning contained in a form of mu'amalah and the targets to be achieved [20]. So, muamalah values are values that originate from Islamic teachings relating to the relationship between humans in order to meet their needs. It is your values that promote justice and the absence of parties who are judged.

\section{Value of Humanities}

Ethics is the science of what is good and what is bad and about moral rights and obligations [21]. Ethical values in pesantren are better known as morality, which is a strong ability to be repeated repeatedly so that it becomes a habit that leads to good and bad [22]. This ethical value or moral value is something that is very urgent to be developed in the pesantren to remember it as an Islamic educational institution. Of course, the main goal of education is not only to make the students have faith and piety but also to have good morals.

Social values are values related to human interaction with others. Social values depart from what is considered good and bad in the social environment. Therefore, this social value is also related to customs in a place. Pesantren, as an educational institution that is inseparable from social life or the surrounding environment, also instills these social values to students in order to equip students with the ability to live well in the social environments.

Aesthetic values are values related to beauty, which are the benchmarks of aesthetic values that are not true or false but beautiful or not beautiful [21]. With the aesthetic value, human life will be more varied. This means that anything humans do is not only seen from the pros and cons but also seen from the beautiful and whether or not. Likewise, with the religious culture in the pesantren, it also continues to cultivate its students to uphold aesthetic values in daily behavior. 


\title{
Value of Nationality
}

The religious culture in pesantren is also inseparable from national values. Pesantren in Indonesia always instills in students to uphold nationalism and patriotism as a form of obligation. In addition to ukhuwah Islamiyah and ukhuwah basyariyah, pesantren also developesukhuwah wathaniyah [23]. The national values are implemented in the form of tasâmuh (tolerance), tawassuth (moderate), and tawâzun (balanced). These values are formulations of thinking method (mahhajul fikr) in fostering and instilling a sense of nationalism to the students [24]. Thus, pesantren, as a religious educational institution, must always cultivate their students to uphold national values so that students have high nationalism.

\section{The Implementation of The Religious Culture Based on Information Technology:a Multidisciplinary Perspective}

\begin{abstract}
A Social Perspective
Pesantren is an educational institution that cannot be separated from the social life of the community. The existence of pesantren is always accompanied by the social development of the surrounding community [25]. The presence of pesantren residents must be able to be a part of the social life of the community and even can provide solutions to problems that exist in their communities. The presence of information technology which is then utilized in the formation and development of religious culture in pesantren in this social perspective can be implemented in the form of developing santri's skills in positive communication through communication and information media. Positive communication referred to here is communication in order to preach the Islamic teachings.

Information technology-based religious culture in pesantren in the form of developing santri skills in positive communication can be implemented by (a) customizing students to actively write in online media, such as online newspapers, online journals; (b) get students used to deliver their da'wah through television, as well as social media such as Facebook, Twitter, Instagram, YouTube and so on; and (c) training students to make creative videos related to Islamic studies, and so on.
\end{abstract}

\section{An Economic Perspective}

In the economic context, the development of the industrial era 4.0 brought a great impact on the development of the global economy. Among them is the rapid development of the business world, and demands that products from the business world can compete globally. One alternative solution to meet these demands is the development of the entrepreneurship sector. The concept of entrepreneurship that is relevant in the industrial era 4.0 belongs to everyone and it is something that can be learned and must be pursued [26].

In response to this, pesantren as an educational institution certainly has a responsibility to prepare its students to be human beings who can compete globally, including in terms of entrepreneurship through the formation of information technology-based entrepreneurship as one form of developing pesantren religious culture. By providing students with entrepreneurial skills, pesantren has prepared students to be able to maintain their lives later when they are already living in the community. This means that students who have graduated from pesantren will have no difficulty to find works or even they can open jobs for others through their entrepreneurial skills. 
Thus, the implementation of the formation of technology-based religious culture in pesantren in an economic perspective can be done as follows:

a) Training and accustoming students to buy and sell in accordance with the demands of the Shari'a through online businesses in order to keep abreast of online business developments that are currently booming;

b) Providing online entrepreneurship training and seminars on entrepreneurship and social media by bringing in experts;

c) Incorporating entrepreneurial learning according to Islamic laws into learning in pesantren;

d) Establishing cooperatives or business centers in pesantren in the context of training students' entrepreneurial skills;

e) Collaborating with Islamic and non-bank financial institutions to help students develop their entrepreneurial skills.

\section{A Psychology Perspective}

According to humanistic psychology, the composition of the human psychological structure consists of the somatic (physical), psychological and neurotic (spiritual) dimensions or the so-called spiritual dimension [27]. With these three dimensions, the main motivation of humans beings is to live meaningfully. If someone succeeds in fulfilling it, it will make their life meaningful and happy. Conversely, if he does not succeed, their lives will be meaningless [28].

As for the context of Islamic psychology, Baharuddin noted, humans are seen as the most perfect beings in terms of their physical and psychological aspects. And the psychological structure of human beings consists of several aspects, i.e.: 1) Al Jism (physical), 2) Al-Nafs (human soul), 3) Al-'Aql and Qalb (mind and heart), 4) Al-Ruh ( spiritual dimension), 5) AlFitrah (human basic potential) [27]. Therefore, the education process in the pesantrens should be able to develop the existing dimensions in the human psychological structure by which students can become meaningful humans.

One effort that can be done to make human life meaningful and not empty is through soul cleansing (tazkiyah al-nafs). Tazkiyatun nafs is a process of purifying the soul, restoring it to its nature, and treating sick souls to be healthy again, through Sufistic therapies [29]. Tazkiyah al-nafs means a process of purification from a bad quality in a person towards a better quality by following and practicing the principles of Islamic law (sharia) [30].

Then, in the context of the formation of religious culture in pesantren, tazkiyah al-nafs can be done in the following ways:

a) Habituation for self-introspection (muhasabah al-nafs), in this case, students are accustomed to correcting their strengths and weaknesses;

b) Habitual prayers and dzikircollectively;

c) Habitual fasting be it obligatory or complementary;

d) The use of social media and other information technologies in the form of emotional and spiritual quotient (ESQ) training, and so on.

As for the process, the conceptual schematic discussion can be seen in the picture below:

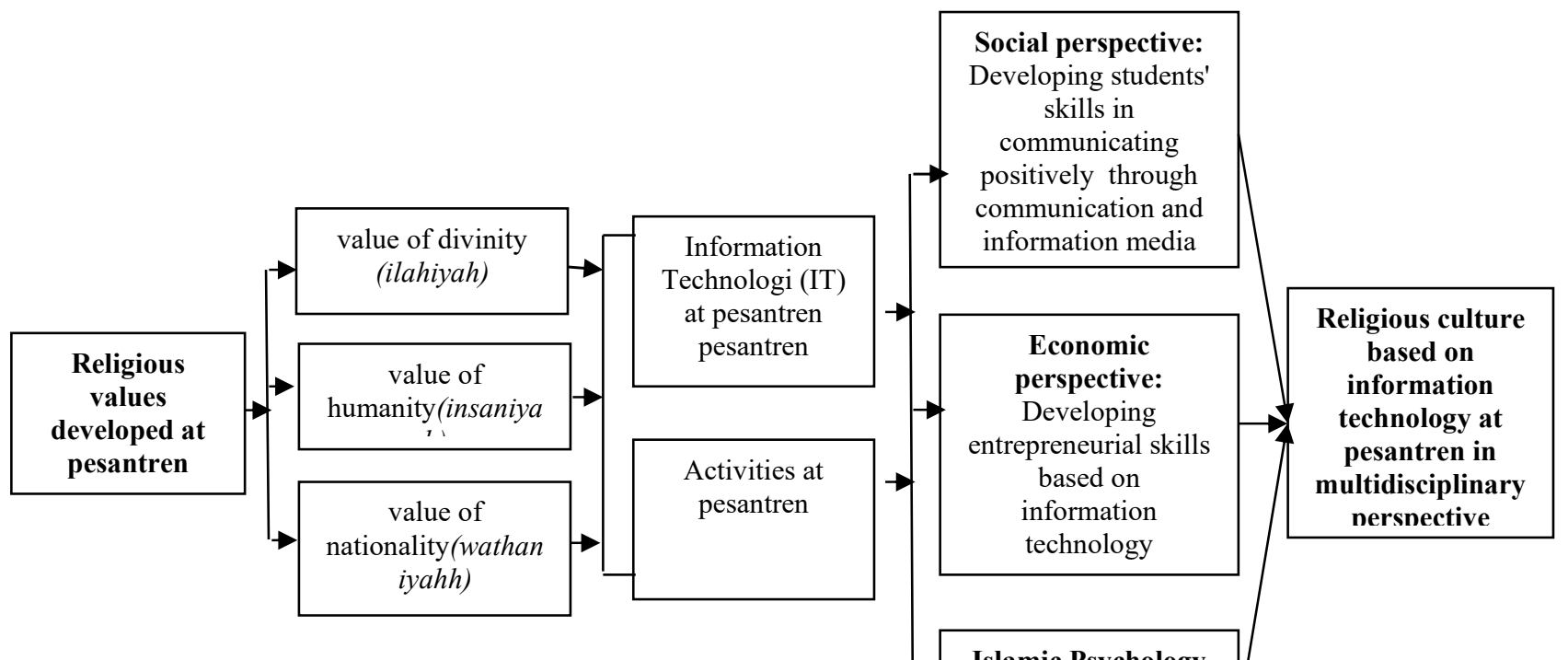


Figure 1. Implementation of the religious culture based on information technology in a pesantren: a multidisciplinary perspective

\section{Conclusion}

Religious values that can be developed in pesantren through the formation of religious culture based on information technology include 1) Divine values, such as faith, worship, and muamalah; 2) Human values, such as ethical, social, and aesthetic ones; 3) Nationality values, such as tasamuh (tolerance), tawasuth (moderate) and tawazun (balanced). The implementation of technology-based religious culture to internalize religious values in pesantren, within a multidisciplinary perspective is as follows: The first is that in a social perspective, it can be done through the development of santri's skills in communicating through information technology-based media, i.e. habituation of writing in online media in which social media is used to preach and making videos- creative videos related to Islamic studies. The second is that, in an economic perspective, the application is carried out through the development of information technology-based entrepreneurial skills in students, including getting the students familiar with shari'a-based business activities, holding entrepreneurial seminars, establishing business centers or cooperatives in pesantren, and establishing cooperation with financial institutions both banks and non-banks. The third is, from a psychological perspective, it can be implemented through tazkiyah al-nafs or purifying the students' souls through self-introspection, dhikr together, habituation, fasting, and emotional and spiritual quotation (ESQ) training. Furthermore, this research recommended further studies on information technology-based religious culture that need to be conducted from other perspectives.

\section{References}

[1] N. Madjid, Bilik-bilik Pesantren Sebuah Potret Perjalanan. Jakarta: Paramadina, 1997.

[2] J. Burhanudin, Mencetak Muslim Modern, Peta Pendidikan Islam Indonesia. Jakarta: Raja Grafindo Persada, 2006.

[3] Mukhibat, "Meneguhkan Kembali Budaya Pesantren dalam Merajut Lokalitas, Nasionalitas, dan Globalitas," Karsa J. Sos. dan Budaya Keislam., vol. 23, no. 2, p. $178,2015$.

[4] M. Nazir, Metode Penelitian, Cet. ke-V. Jakarta: Ghalia Indonesia, 2003.

[5] S. dan H. K. Elo, "The Qualitative Content Analysis Process," J. Adv. Nurs., vol. 62, no. 1 , p. 108, 2007.

[6] M. Fathurrohman, "Pengembangan Budaya Religius dalam Meningkatkan Mutu Pendidikan," Ta'allum, vol. 4, no. 1, p. 28, 2016.

[7] R. S.P., Organizational Behaviour. New Jersey: Prentice Hall, 1991.

[8] C. Chotimah, Komplemen Manajemen Pendidikan Islam. Yogyakarta: Sukses Offset, 2014.

[9] Suprapno, "Implementasi Budaya Religius," Tarbawi J. Stud. Pendidik. Islam, vol. 05, no. 01, p. 64, 2018.

[10] S. Ali, Reformasi Paradigma Keilmuan Islam. Malang: UIN Maliki Press, 2013.

[11] F. Hanun, "Pemanfaatan Teknologi Informasi (TI) di Pesantren," Komunika, vol. 14, no. 1, p. 2, 2011.

[12] Rahmat, Penerapan Teknologi Informasi dan Komunikasi dalam Pendidikan di Indonesia. Bandung: Remaja Rosdakarya, 2005. 
[13] M. Isna, Diskursus Pendidikan Islam. Yogyakarta: Global Pustaka Utama, 2001.

[14] Mulyana, Mengartikulasikan Pendidikan Nilai. Bandung: Alfabeta, 2004.

[15] H. Nisa, "Nilai-Nilai Ilahiyat dalam Pendidikan sebagai Syarat Pembentukan Kepribadian Muslim', , No. 7, (2016), 15,”J. Pusaka, no. 7, p. 15, 2016.

[16] Jalaluddin, Teologi Pendidikan. Bandung: Raja Grafindo Persada, 2001.

[17] A. A.-H. B. M. B. I. B. U. A. Ali, Tafsir Khozin, Lubabu Ta'wil fi Ma'ani Tanzil, Cet. I. Beirut: Dar-al-Kutub al-Ilmiyah, 1995.

[18] M. Q. Sihab, Tafsir Al-misbah, Cet IV. Jakarta : Lentera Hati, 2006.

[19] Nurfaizal, "Prinsip-Prinsip Muamalah dan Inplementasinya dalam Hukum Perbankan Indonesia," Huk. Islam, vol. XIII, no. 01, p. 1, 2013.

[20] Dimyati, "Dimyati, 'Kontekstualisasi Nilai-Nilai Fiqh Mua'malah dalam Aktivitas Perekonomian', , Volume 671 Nomor 1 Tahun 2014,” Irtifaq, vol. 1, no. 1, p. 67, 2014.

[21] T. W. Abadi, “Aksiologi: Antara Etika, Moral, dan Estetika," Kanal J. Ilmu Komun., vol. 4, no. 4, p. 193, 2016.

[22] U. A. Syafri, Pendidikan Krakter Berbasis Al-Qur'an. Jakarta, Rajawali Pers, 2010.

[23] W. F. Riyanto, Studi Islam Indonesia, (1950-2014), Rekonstruksi Sejarah Perkembangan Islam Integratif di Pascasarjana PTAI \& Annual International Conference on Islamic Studies (AICIS). Pekalongan: STAIN Pekalongan Press, 2014.

[24] M. Hubi, Zindan Baynal dan Halimi, “Tipe dan Pola Pembentukan Sikap Wathaniyah (Kebangsaan) Yang Dilakukan di Lingkungan Pesantren Al-Hikamussalafiyah Cipulus Purwakarta," JIPIS J. Ilmu Pendidik. dan Ilmu Sos., vol. 26, no. 2, p. 43, 2018.

[25] D. dan Umiarso, "Pesantren dan Perubahan Sosial: Optimalisasi Modal Sosial Bagi Kemajuan Masyarakat," Al- A'raf J. Pemikir. Islam dan Filsafat, vol. XIV, no. 1, p. 8, 2017.

[26] B. H. dan M. K. Perdagangan, "Mendag Dorong Semangat Kewirausahaan Mahasiswa di Era Perdagangan Bebas dan Industri 4.0."

[27] Baharuddin, Paradigma Psikologi Islami: Studi tentang Elemen Psikologi dari AlQur'an. Yogyakarta: Pustaka Pelajar, 2004.

[28] H. D. Bastaman, Integrasi Psikologi Dengan Islam; Menuju Psikologi Islami. Jogjakarta: Pustaka Pelajar, 1997.

[29] M. Sholihin, Terapi Sufistik. Bandung: CV. Pustaka Setia, 2004.

[30] I. A. G. Azmi, "Human Capital Development And Organizational Performanc: A

Focus On Islamic Perspective," Syariah J., vol. 17, no. 2, p. 357, 2009. 